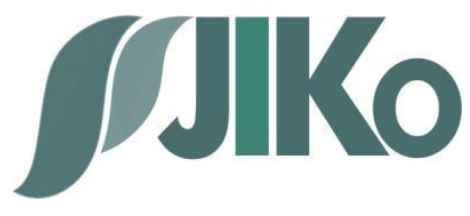

\title{
Why does Gojek fail to maintain the Top Brand Award?
}

Maaz Ud Din ${ }^{1}$, Ana Kadarningsih ${ }^{2}$, Nenny Ariani ${ }^{3}$

Ph.D candidate at Swabi University, Pakisan ${ }^{l}$

Management Department, Universitas Dian Nuswantoro, Indonesia ${ }^{2}$

Accounting Department, STIE AMM Mataram, Indonesia ${ }^{3}$

Ph.D candidate at Universitas Diponegoro, Indonesia ${ }^{3}$

Received: 19-02-2020| Revision: 02-04-2020 | Accepted: 28-08-2020

DOI: https://doi.org/10.22219/jiko.v5i03.11343

\begin{abstract}
This study aims to understand the factors that cause Gojek to fail to maintain the Top Brand Award status. To answer the research objectives, the study build a conceptual framework with brand images as a mediating variable of service quality, product, promotion, and price on purchasing decisions. The research sample was 100 respondents. Test of research instruments using factor analysis for validity, and Cronbach Alpha for reliability and use multiple linear regression for data analysis. The result of this study found that the failure of Gojek to maintain the status of the Top Brand Award was caused by the company's lack of strengthening the driving variables. The statement is based on the finding that only price having a significant positive effect on brand images, while service quality, product, and promotion are not significant. The result makes the total impact of exogenous variables less optimal in increasing purchasing decisions.
\end{abstract}

Keywords: Gojek; brand images; purchasing decision

\section{Introduction}

Gojek rating has declined compared to its competitors in 2017 and 20184. The result of previous research also found that Grab as Gojek competitor is the most favorite online transportation being chosen by customers (Burhanuddin, G., \& Tulung, 2018). The increasingly fierce business competition, especially competition from similar companies, makes companies increasingly demanded to move faster in terms of attracting consumers. So, companies that apply marketing concepts need to pay close attention to consumer behavior and factors that influence purchasing decisions in marketing efforts for a product that is carried out. One way to achieve company goals is to know what the needs and desires of consumers or the target market and to provide expected satisfaction more effectively and efficiently than competitors (Kotler, 2012).

Research at the chain stores shows that service quality has a positive and significant impact on purchasing decision. In addition, this study also revealed that the private brand images had a positive and significant impact on purchasing decision

\footnotetext{
${ }^{1}$ maazudin@gmail.com

2 ana.kadarningsih@dsn.dinus.ac.id

3 ariani@gmail.com

${ }^{4}$ See more detail at www.topbrand-award.com
} 
(Soltani, Esfidani, Jandaghi, \& Soltaninejad (2016). Meanwhile, research in the field of airlines gives the result that service quality has a direct relationship on purchasing decision. Furthermore, it was also found that customer satisfaction and brand image mediated service quality and purchasing decision (Abid Saleem, Zahra, \& Yaseen, 2017).

Beside, (Soltani et al., 2016) who revealed that brand image have a direct influence on purchasing decisions. P. C. Wu et al., (2011) also revealed the store image that has a direct and positive effect on the purchase intention. Some similar studies also show the same results with slightly different characteristics (Jahanzeb, Fatima, \& Butt, 2013); (C.-C. Wu, 2011); (Saleem \& Raja, 2014); (Khan, Aabdean, Salman, Nadeem, \& Rizwan, 2016)

Literature shows that service quality and brand images have a significant effect on purchasing decision. However, there are three other things which also cannot be ignored, namely product quality, promotion, and price. Product quality has impact significantly in purchasing decision Girsang, Rini, \& Gultom (2020); Febriati \& Respati (2020); Darojat (2020); Amron (2018); Waluya \& Iqbal (2019); and Santoso (2016). Product quality also can moderate significantly between brand image and brand equity Ansary, M, \& Hashim (2017). Another research also shows that the product quality has a positive and significant effect on brand image (Febriati \& Respati, 2020); (Khan et al., 2016); (Chinomona \& Maziriri, 2017); (Pranata, Syah, \& Anindita, 2020). Brand image also is influenced by product quality positively (Kirca, Randhawa, Talay, \& Akdeniz, 2019).

Meanwhile, major research shows that promotion has a positive influence on brand image (Buil, de Chernatony, \& Martínez, 2013). Promotion has positive and significant influence on purchasing decision (Leksono \& Herwin, 2017); (Astut, 2019); (Ariatmaja \& Rastini, 2017). Another research also indicates that promotion has relationship with brand image positively and significantly (Chakraborty \& Bhat, 2018); (Kumar \& Patra, 2017); (Tadesse, 2019); (Schivinski, Bruno, \& Dabrowski, 2016); (Bilgin, 2018); (Marcel, 2009); (Yaman, 2018); (Seo \& Park, 2018). How about price? (Amron, 2018); (Ariatmaja \& Rastini, 2017); (Leksono \& Herwin, 2017); (Santoso, 2016); (Burhanuddin et al., 2018) revealed that price has a positive and significant influence on purchasing decision. In addition, price also has a significant relationship with brand image (Anselmsson, Bondesson, \& Johansson, 2014). The statement also support by (Popp \& Woratschek, 2017); (Marcel, 2009); (Leksono \& Herwin, 2017); (Almendros \& Garcia, 2014).

Based on several literature that have been described, in general, this paper builds a simple hypothetical framework that Gojek's declining performance can be resolved by increasing service quality, product quality, promotion, and price to create a brand image that ultimately improves sales performance. This research contributes to understanding the causes of the decline in Gojek's performance, which failed to maintain the Top Brand award. These findings can be used by academics as well as practitioners as literature to emphasize the importance of service quality, product, promotion, and price to reinforce brand image and finally level up the purchasing decision. 


\section{Research Method}

Population of this study is all customer in Semarang City that use GOJEK services. 100 samples were taken with purposive sampling techniques with criterion that ask before giving questionnaire such as domiciled in Semarang city, age of respondent at least 17 years old and at least have used the Gojek application 3 times a week. A total of 125 questionnaires were spread out and the feedback rate was $86,4 \%$ which 108 questionnaires received but 8 questionnaires incomplete filled. The questionnaire adopted uses a five-point Likert scale, from $1=$ strongly disagree to $5=$ strongly agree. Techniques of collected data were used to fulfill according to data to the problem so that normal distribution was used in quantitative data in this study.

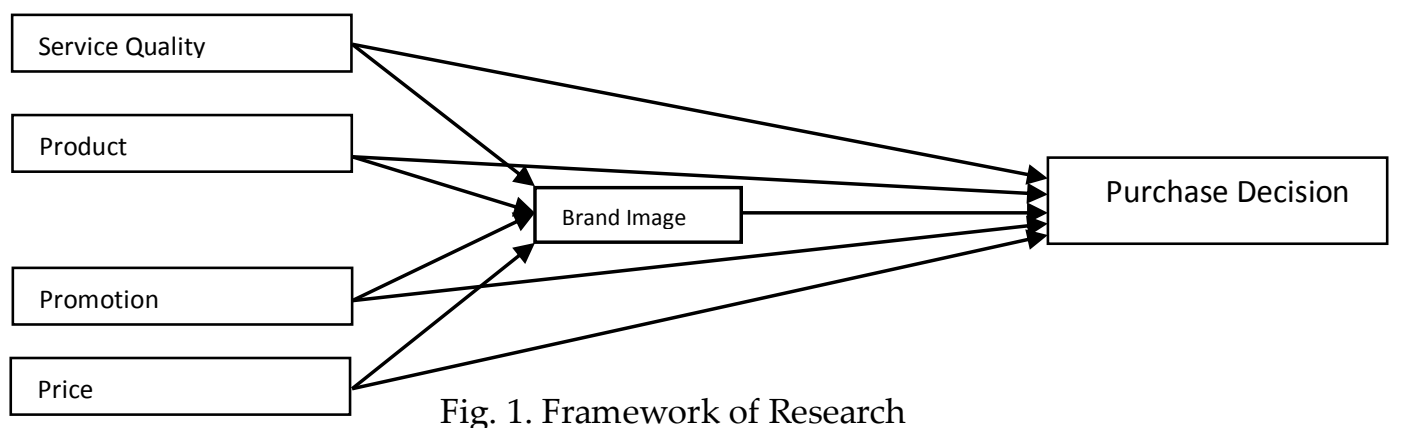

This study used four independent variables namely service quality, product, promotion, and price. Service quality variables were reflected in 5 indicators such as physical evidence, reliability, responsiveness, assurance, empathy. Product variables were measured from 5 indicators: product expectations, privileges, abilities, conformity, impressions. While the promotion variable has 4 indicators that is a lot of information, interesting endorsers, easy to remember, messages are easy to understand and price variables are reflected in 3 indicators which are pricing or low fares, suitability of the rates with the benefits of the services provided, the prices set are in accordance with competitors. The intervening variable in this study is brand image that reflected by 4 indicators such as product attribute and benefits, people and relationships, values and programs, company credibility. And dependent variable is purchase decision and reflected by 4 indicators which are confidence to make purchases, purchases as needed, planning the right purchase and information search about the product. The research framework can be seen in Fig 1. Test research instruments use factor analysis for validity and alpha Cronbach for reliability ${ }^{5}$. Analysis tools use multiple linear regression with SPSS.

\section{Result and Discussion}

The results of the regression output in Table 1 show that the significance value of the service quality variable is 0.092 ; product quality variable 0.279 ; promotion variable 0.175 and price variable 0.010 , so that only the price has a direct influence on brand image with a significance value of 0.010 . $R$ Square value in the model summary of 0.654 indicates that service quality, product, promotion and price variables can

${ }^{5}$ For more detail about validity and reliability, please see at https://stats.idre.ucla.edu/?s=cronbach+alpha 
explain brand image variable by $65.4 \%$ and $34.6 \%$ are influenced by other variable outside the model being tested. The result contradicts some literature that shows service quality Amron (2018); Darojat (2020); Febriati \& Respati (2020); Girsang, Rini, \& Gultom (2020); and Waluya \& Iqbal (2019), product (Chinomona \& Maziriri, 2017); (Febriati \& Respati, 2020); and (Khan et al., 2016), and promotion (Ariatmaja \& Rastini, 2017); (Astut, 2019); and (Leksono \& Herwin, 2017) has a significant positive relationship with brand images.

Table 1. Model structural 1

\begin{tabular}{lccc}
\hline \multicolumn{1}{c}{ Variable } & R Square & Beta & Significant \\
\hline SQ & & .238 & .092 \\
PROD & .654 & .143 & .279 \\
PROM & & .200 & .175 \\
PR & .294 & .010 \\
\hline BI (Dependent Variable) & \multicolumn{2}{l}{} \\
\hline Note: SQ: Service Quality; PROD: Product; PROM: Promotion; PR: Price; BI: Brand Image
\end{tabular}

Table 2. Model structural 2

\begin{tabular}{lccc}
\hline \multicolumn{1}{c}{ Variable } & R Square & Beta & Significant \\
\hline SQ & & .258 & .011 \\
PROD & & .190 & .043 \\
PROM & .841 & .227 & .030 \\
PR & & .172 & .036 \\
BI & & .148 & .042 \\
\hline PD (Dependent Variable) & & & \\
\hline
\end{tabular}

Note: SQ: Service Quality; PROD: Product; PROM: Promotion; PR: Price; BI: Brand Image; PD: Purchasing Decision

Based on the results of data analysis in this study, Gojek's brand image should be improved by optimizing service quality, product, and promotion. However, research conducted in Semarang showed that the three variables were not significant. Therefore, we assume that the service quality and products offered by Gojek must be more innovative. For promotion, this paper suggests that development in each region can pay attention to the cultural characteristics of each region so that promotion is more psychologically touching to the community; this is important to be one of the deviation strategies. ${ }^{6}$

The direct influence of services quality on purchasing decision is 0.258 , while the indirect influence of services quality through brand images on purchasing decision is 0.035 . It means that the value of the direct influence of service quality on purchasing decision is greater than the influence of services quality through brand images. The total effect of services quality on purchasing decision directly and indirectly becomes 0.273. The direct influence of the product on purchasing decision is 0.190 , while the indirect influence of the product through brand images on purchasing decision is 0.021. The total effect of the product on purchasing decision directly and indirectly is

${ }^{6}$ For more detail about cultural marketing please see at https://www.columnfivemedia.com/5-culture-marketing-examples 
0.164. Meanwhile, direct effect of promotion on purchasing decision is 0.227 , while the indirect effect of promotion through brand images on purchasing decision is 0.052 . The total effect of promotion on purchasing decision directly and indirectly is 0.252 . The direct effect of price on purchasing decision is 0.172 , while the indirect effect of price through brand images is 0.044 .

Table 3. Results of structural model path analysis

\begin{tabular}{lccc}
\hline \multicolumn{1}{c}{ Variable } & Direct Influence & Indirect Influence & Totally of Influence \\
\hline SQ & .258 & .035 & .273 \\
PROD & .190 & .021 & .164 \\
PROM & .227 & .052 & .252 \\
PR & .172 & .044 & .338 \\
BI & .148 & &
\end{tabular}

PD (Dependent Variable)

Note: SQ: Service Quality; PROD: Product; PROM: Promotion; PR: Price; BI: Brand Image; PD: Purchasing Decision

Data analysis and discussion indicate that Gojek still needs to improve its brand images. Commonly, when Gojek can optimize the role of service quality, product quality, and promotion in increasing brand image or making service quality, product and promotion have a significant positive effect (see Table 1). The total effect of each independent variable, as in Table 3, will automatically increase. Therefore, based on the conceptual framework, this study has answered the research question that was proposed. Gojek failed to maintain the Top Brand award because the company did not optimize service quality, product, and promotion in encouraging purchasing decisions through brand images.

\section{Conclusions}

The findings of this study indicate that the hypothesis regarding Gojek's lack of optimism in strengthening several variables that affect the performance of the highest service quality, product, and promotion. This conclusion is supported by the finding that only the price variable significantly influences brand images. Therefore, this paper provides simple suggestions Gojek must be improve service quality, product diversification, and promotion of materials that are more touching to the consumers.

\section{Acknowledgment}

The authors wish to thank Difa Adi Suwandaru. This work was supported in collecting data from questionnaire that spread to Gojek consumer in Semarang City, Indonesia, Central Java.

\section{References}

Abid Saleem, M., Zahra, S., \& Yaseen, A. (2017). Impact of Service Quality and Trust on Repurchase Intentions : The Case of Pakistan Airline Industry. Asia Pasific Journal of Marketing and Logistics, 29(5), 1136-1159. doi:10.1108/APJML-10-20160192 
Almendros, E. C., \& Garcia, S. D. B. (2014). Do online discounts and free gifts damage brand image of service ? The moderating role of promotion-pronneness. Springer-Verlag Berlin Heidelberg. doi:10.1007/s11628-014-0255-9

Amron. (2018). Effects of Product Quality, Price and Brand Image on The Buying Decision of City Car Product. Archives of Business Research, 6(4), 1-8. doi:10.14738/abr.64.4374

Ansary, A., M, N., \& Hashim, H. N. (2017). Brand Image and Equity : The Mediating Role of Brand Equity Drivers and Moderating Effects of Product Type and Word of Mouth. Springer-Verlag Berlin Heidelberg, JEL M310. doi:10.1007/s11846017-0235-2

Anselmsson, J., Bondesson, N. V., \& Johansson, U. (2014). Brand Image and Customers' Willingness to Pay a Price Premium for Food Brands. Journal of Product and Brand Management, 23(2). doi:10.1108/JPBM-10-2013-0414

Ariatmaja, I. G. A. D. D., \& Rastini, N. M. (2017). Peran Brand Image Memediasi Daya Tarik Promosi dan Kewajaran Harga Terhadap Keputusan Penggunaan Jasa Transportasi. E-Jurnal Manajemen Unud, 6(9), 4689-4715.

Ashraf, S., Ilyas, R., Imtiaz, M., \& Ahmad, S. (2018). Impact of Service Quality, Corporate Image and Perceived Value on Brand Loyalty with Presence and Absence of Customer Satisfaction : A Study of Four Service Sectors of Pakistan. International Journal of Academic Research in Business and Social Sciences, 8(2), 452474. doi:10.6007/IJARBSS/v8-i2/3885

Astut, Y. T. S. (2019). Pengaruh Strategi Periklanan dan Sales Promotion Terhadap Keputusan Pembelian Produk Smartphone Oppo dengan Brand Image Sebagai Variabel Moderasi. Jurnal SIMBA.

Bilgin, Y. (2018). The Effect of Social Media Marketing Activities On Brand Awareness, Brand Image, and Brand Loyalty. Business and Management International Journal (BMIJ), 6(1), 128-148. doi:10.15295/bmij.v6i1.229

Budiyanto, T., Kojo, C., \& Tawas, H. N. (2016). Strategi Promosi, Kualitas Produk, dan Desain Terhadap Keputusan Pembelian dan Minat Mereferensikan Rumah Pada Puri Camar Liwas PT. Camar Sapta Ganda. Jurnal Berkala Ilmiah Efisiensi, 16(4).

Buil, I., de Chernatony, L., \& Martínez, E. (2013). Examining the role of advertising and sales promotions in brand equity creation. Journal of Business Research, 66(1), 115-122. doi:10.1016/j.jbusres.2011.07.030

Burhanuddin, R. A., G., W. F., \& Tulung, J. E. (2018). Analytical Hierarchy Process Method in Selecting Online Transportation in Manado. Jurnal EMBA, 6(2), 748757.

Camarero, C., Samaniego, M. J. G., \& Vicente, E. (2012). Determinants of Brand Equity in Cultural Organizations : The Case of Art Exhibition.pdf $>$. The Service Industries Journal, 32(9), 1527-1549. doi:10.1080/02642069.2011.567414

Chakraborty, U., \& Bhat, S. (2018). Credibility of Online Reviews and Its Impact on Brand Image. Management Research Review, 41(1), 148-164. doi:10.1108/MRR-062017-0173 
Jahanzeb, S., Fatima, T., \& Butt, M. M. (2013). How Service Quality Influences Brand Equity. International Journal of Bank Marketing, 31(2), 126-141. doi:10.1108/02652321311298735

Khan, M. N., Aabdean, Z.-U., Salman, M., Nadeem, B., \& Rizwan, M. (2016). The Impact of Product and Service Quality on Brand Loyalty : Evidence from Quick Service Restaurants. American Journal of Marketing Research, 2(3), 84-94.

Kirca, A. H., Randhawa, P., Talay, M. B., \& Akdeniz, M. B. (2019). The interactive effects of product and brand portfolio strategies on brand performance: Longitudinal evidence from the U.S. automotive industry. International Journal of Research in Marketing. doi:10.1016/j.ijresmar.2019.09.003

Krafft, Manfred. Arden, Christine M. Verhoef, Peter C. (2017). Permission Marketing and Privacy Concern - Why Do Customers (Not) Grant Permissions ?. Journal of Interactive Marketing, 39, 39-54.

Kumar, S., \& Patra, S. (2017). Does Promotion Mix Really Help To Enhance Brand Equity : A Literature Review. Indian Journal of Commerce and Management Studies, 8(2), 80-86. doi:10.18843/ijcms/v8i2/11

Leksono, R. B., \& Herwin. (2017). Pengaruh Harga dan Promosi Grab Terhadap Brand Image Yang Mempengaruhi Keputusan Pembelian Konsumen Pengguna Transportasi Berbasis Online. Jurnal Riset Manajemen dan Bisnis (JRMB) Fakultas Ekonomi UNIAT, 2(3), 381-390.

Mao, Y., Ma, J., Bonaiuto, F., \& Banaiuto, M. (2020). Apple or Huawei : Understanding Flow, Brand Image, Brand Identity, Brand Personality and Purchase Intention of Smartphone. Journal of Sustainability, 3391, 1-22. doi:10.3390/su12083391

Marcel, A. R. (2009). The Effect of The Marketing Communication and Price Promotion Toward Brand Equity. Business and Entrepreneurial Review, 9(1), 41-50.

Popp, B., \& Woratschek, H. (2017). Consumer-Brand Identification Revisited : An Integrative Framework of Brand Identification, Customer Satisfaction and Price Image and their Role for Brand Loyalty and Word-of Mouth. Journal of Brand Management. doi:10.1057/s41262-017-0033-9

Pranata, A., Syah, T. Y. R., \& Anindita, R. (2020). Interpersonal Trust Impact on Moderate Customer Satisfaction by Product Quality and Brand Image. Journal of Multidisciplinary Academic, 4(1), 34-41.

Saleem, H., \& Raja, N. S. (2014). The Impact of Service Quality on Customer Satisfaction, Customer Loyalty and Brand Image : Evidence from Hotel Industry of Pakistan. Journal of Scientific Research, 19(5), 706-711. doi:10.5829/idosi.mejsr.2014.19.5.21018

Santoso, I. (2016). Peran Kualitas Produk dan Layanan, Harga dan Atmosfer Rumah Makan Cepat Saji terhadap Keputusan Pembelian dan Kepuasan Konsumen. Jurnal Manajemen Teknologi, 15(1), 94-109. doi:10.12695/jmt.2016.15.1.7

Schivinski, Bruno, \& Dabrowski. (2016). The Effect of Social Media Communication on Consumer Perceptions of Brands. Journal of Marketing Communications, 22(2), 189-214.

Seo, E.-J., \& Park, J.-W. (2018). A study on the effects of social media marketing activities on brand equity and customer response in the airline industry. Journal of Air Transport Management, 66, 36-41. doi:10.1016/j.jairtraman.2017.09.014 
Soltani, M., Esfidani, M. R., Jandaghi, G., \& Soltaninejad, N. (2016). The effect of service quality on private brand image and purchase intention in the chain stores of ETKA. World Scientific News, 47(2), 202-216.

Suher, Kemal. Ispir, Bilge. (2011). Permission Based Mobile Marketing and SMS Ad Avoidance. Journal of Yasar University, 21(6), 3633-3647.

Suryaningsih, I. B. (2020). Co-Shopper and Price Moderation in The Influence of Tourist and Brand Images on Purchase Intention. Jurnal Bisnis dan Manajemen, 12(2), 124-138. doi:10.26740/bisma.v12n2.p124-139

Tadesse, E. (2019). The Effect of Promotional Practice on The Brand Image : The Case of Eden Business Share Company. Addis Abeba, Ethiopia.

Theotokis, A., Pramatari, K., \& Tsiros, M. (2012). Effects of Expiration Date-Based Pricing on Brand Image Perceptions. Journal of Retailing, 88(1), 72-87. doi:10.1016/j.jretai.2011.06.003

Waluya, A. I., \& Iqbal, M. A. (2019). How Product Quality, Brand Image, and Customer Satisfaction Affect the Purchase Decision of Indonesian Automotive Customers. International Journal Service, Economics and Management, 10(2), 177-193. doi:10.1504/IJSEM.2019.100944

Wu, C.-C. (2011). The Impact of Hospital Brand Image on Service Quality, Patient Satisfaction and Loyalty. African Journal of Business Management, 5(12), 48734882. doi:10.5897/AJBM10.1347

Wu, P. C., Yuh Yeh, G. Y., \& Hsiao, C.-R. (2011). The effect of store image and service quality on brand image and purchase intention for private label brands. Australasian Marketing Journal (AMJ), 19, 30-39. doi:10.1016/j.ausmj.2010.11.001

Yaman, Z. (2018). The Effect of Word Mouth Marketing on the Purchase Behaviour Via Brand Image and Perceived Quality. Montenegrin Journal of Economics, 14(2), 175-182. doi:10.14254/1800-5845/2018.14-2.12

Yessica Oscar, K. (2019). Pengaruh Brand Image, Persepsi Harga, dan Service Quality Terhadap Keputusan Pembelian Konsumen. Jurnal Muara Ilmu Ekonomi dan Bisnis, 3(1), 20-28. doi:10.24912/jmieb 